\title{
IDENTIFICATION AND EVALUATION OF DEVELOPMENT TRENDS IN THE CONURBATION OF THE CITIES OF MARTIN AND VRÚTKY OVER THE LAST 23 YEARS
}

\author{
Jana Nozdrovická, Martina Turanovičová, Petra Gašparovičová
}

\begin{abstract}
In this paper we evaluate the development trends in the conurbation of the cities of Martin and Vrutky which is situated in the northern part of central Slovakia. Two time frames were chosen for our study. The first is the period from 1993 to 2003. It is the period before the accession of the Slovak republic to the European Union. The second period is from 2003 to 2016 - after Slovakia's accession to the European Union. The aim of this paper is to identify and evaluate development trends in the conurbation of the cities of Martin and Vruttky based on the comparison of land use changes over the last 23 years. We discovered that there were more significant changes in the first period (1993-2003). The strongest development trend in this area was afforestation which covered and area of 733.12 ha.
\end{abstract}

Keywords: secondary landscape structure, land use changes, development trends

\section{Introduction}

In recent years, research of landscape development using the historical documents has been on the rise not only in Slovakia but also in other countries of the world. It represents a highly current research issue. That is related, among other things, to the relatively good availability of historical maps as well as the general orientation of research on the cultural landscape.

In this paper we focus on the analysis of land use changes. No author has ever dealt with our study area which consists of two cities. Despite their independence there live in tight social and economic bond. Therefore we decided to study this area as a conurbation. We chose the period between 1993 and 2003 for the analysis of historical landscape structure and the year 2016 for the analysis of present landscape structure. Our aim is to identify and evaluate development trends in the conurbation of the cities of Martin and Vrútky based on the comparison of land use changes over the last 23 years.

\section{Theoretical-methodological bases}

The landscape is constantly changing under the influence of natural processes and society's pressure which is due to the diversity of natural conditions 
and social interest gain great spatial differentiation (Cebecauerová and Cebecauer, 2005). Human interventions to the landscape are most visibly reflected by the secondary landscape structure as a result of land use. A secondary landscape structure is a set of personally influenced, transformed, created material elements of the landscape that cover the earth's surface (Miklós and Izakovičová, 1997). Changes in landscape structure significantly affect its ecological stability (Lipský, 2000), as well as biological (Löfvenhaft et al., 2004), environmental and aesthetic value (Nassauer, 1995). The understanding of landscape changes requires a sound understanding of the underlying processes that can be triggered by different driving forces (Hersperger et al., 2009, Hreško et al., 2008). We can distinguish five major types of driving forces: political, economic, cultural, technological and natural/spatial (Bürgi et al., 2004; Schneeberger et al., 2007). One possible way to identify landscape development is to use the available historical map data and its processing in geographic information systems (GIS) (Izakovičová, Mederly, Petrovič, 2017, Haladová, Petrovič, 2017, Havlíček et al., 2018, Munteanu et al., 2017, Lieskovský et al., 2018).

In 2016, the map of the present landscape structure for 2016 was created by identifying the landscape elements using satellite images made in 2015 (Mapy.cz) and data from a field survey that was ongoing in 2016. The map of historical landscape structure (HLS) for 2003 was created using the satellite images made in 2003 (Eurosense s. r. o 2003). The map of historical landscape structure (HLS) for 1993 was created using the topographical maps on a scale of 1:10 000, which were provided by the Topographical Institute of Banská Bystrica. For the classification of landscape elements, a modified legend according to Petrovič et al. (2009) was used. We used the second hierarchical level where 18 classes were identified (Table 1). The visualization of all maps and data processing was realised using Geographic Information Systems - QGIS 2.16.2 software.

Table 1: Secondary landscape structures (SLS) legend

\begin{tabular}{|c|c|c|c|}
\hline SLS1 & Name 1 & SLS2 & Name 2 \\
\hline \multirow{3}{*}{1} & \multirow{3}{*}{ Tree and shrub vegetation } & 11 & Forest \\
\hline & & 12 & Transitional woodlands/shrubs \\
\hline & & 13 & Non-forest timber vegetation \\
\hline \multirow{2}{*}{2} & \multirow{2}{*}{ Grasslands } & 21 & Meadows and pastures \\
\hline & & 22 & Permanent grassland \\
\hline \multirow{4}{*}{3} & \multirow{4}{*}{ Agriculture crops } & 31 & Arable land \\
\hline & & 32 & Gardens \\
\hline & & 33 & Multiannual cultures \\
\hline & & 34 & Mosaics of agricultural crops \\
\hline \multirow[b]{2}{*}{4} & \multirow{2}{*}{$\begin{array}{l}\text { Sub-soil outcrops and raw } \\
\text { soils }\end{array}$} & 41 & Sub-soil outcrops and raw soils (natural) \\
\hline & & 42 & $\begin{array}{l}\text { Sub-soil outcrops and raw soils } \\
\text { (artificial) }\end{array}$ \\
\hline
\end{tabular}




\begin{tabular}{|c|l|c|l|l|}
\hline SLS1 & Name 1 & SLS2 & Name 2 \\
\hline \multirow{2}{*}{5} & \multirow{2}{*}{ Surface water and wetlands } & 51 & Water courses \\
\cline { 3 - 4 } & & 52 & Standing waters and wetlands \\
\hline \multirow{4}{*}{6} & \multirow{4}{*}{ Settlement and built-up } & 61 & Housing and complex amenities \\
\cline { 3 - 4 } & areas & 62 & Urban and technical vegetation \\
\cline { 3 - 4 } & & 63 & Sports facilities \\
\cline { 3 - 4 } & & 64 & Recreational facilities and resort \\
\cline { 3 - 4 } & & 65 & Industrial and technical objects and areas \\
\cline { 3 - 4 } & & 66 & Transport objects and areas \\
\hline
\end{tabular}

Attribute tables for individual maps-layers were exported to the MS EXCEL data format, which allowed us in the following steps to process statistics and create tables. The areas of individual elements of secondary landscape structure (SLS) as well as their percentage of the total researched area were calculated for each of the monitored years. Consequently, merged layers were created for the periods 19932003, 2003-2016 and the changes in the SLS that occurred in the researched area were evaluated in the individual monitored periods. Using the classification scheme according to Feranec et al. (2002) and Cebecauerová (2007), we identified 14 development trends in land use changes. The code mark is stated in Table 2.

Table 2: Development trends legend

\begin{tabular}{|c|c|c|l|}
\hline $\mathbf{1}$ & Unchanged & $\mathbf{8}$ & Agricultural extensification \\
\hline $\mathbf{2}$ & Urbanisation & $\mathbf{9}$ & Afforestation \\
\hline $\mathbf{3}$ & Deurbanisation & $\mathbf{1 0}$ & Deforestation \\
\hline $\mathbf{4}$ & Industrialization & $\mathbf{1 1}$ & Flooding \\
\hline $\mathbf{5}$ & Deindustrialisation & $\mathbf{1 2}$ & Draining \\
\hline $\mathbf{6}$ & Exploitation of mineral resources & $\mathbf{1 3}$ & Environment remediation \\
\hline $\mathbf{7}$ & Agricultural intensification & $\mathbf{1 4}$ & Loss of agricultural land \\
\hline
\end{tabular}

\section{Localization of the study area}

The study area (8 591.28 ha) is situated in the northern part of Slovakia in the Žilina region and the Martin district. It includes two cities: Martin which is situated in the southern part of the study areas and Vrútky which is situated in the northern part. These cities belong into the geomorphological unit of the Malá Fatra Mts. which covers the western part of the study area and the geomorphological unit of the Turčianska kotlina Basin which covers eastern parts. The Turiec river is the main watercourse of the city of Martin. It passes through its area and flows into the Váh river, which crosses the city of Vrútky in its northern part (Map 1). 
Map 1: Localization of the study area within the Slovak Republic

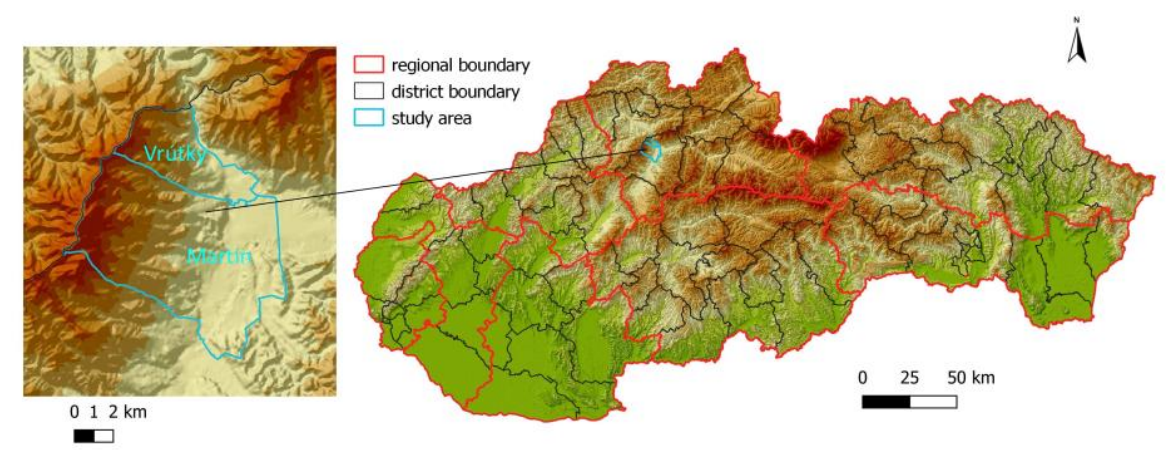

\section{Results and discussion}

\section{Historical landscape structure in the conurbation of the cities of Martin and Vrútky in 1993}

In 1993, we identified that there were 17 areal landscape elements in the study area (Table 3). The group of tree and shrub vegetation occupied the largest part of the study area (3932.49 ha). The most widespread landscape element were forests (3760.95 ha). The group of agricultural crops elements covered an area of 1963.40 ha, out of which the most widespread landscape element was arable land (1416.21 ha). Arable land was represented mostly by large-block fields. The group of grasslands (1321.06 ha) and the group of settlement and built-up areas (1246.52 ha) occupied almost the same area. The group of sub-soil outcrops and raw soils had the lowest areal representation of 40.97 ha.

\section{Historical landscape structure in the conurbation of the cities of Martin and Vrútky in 2003}

In 2003, there were 17 areal landscape elements identified in the study area (Table 3). During this year, the group of tree and shrub vegetation still occupied the largest part of the study area 4635.47 ha. Forests represented an area of 3 934.70 ha. Compared to 1993, the area of all landscape elements from the group of tree and shrub vegetation increased. The second largest area was again represented by the group of agricultural crop elements ( 2019.18 ha). The group of settlement and built-up areas occupied an area of 1383.71 ha. Compared to 1993, a significant decline was recorded in the group of grasslands elements (449.79 ha). The lowest areal representation of approximately 31.74 ha had a group of sub-soil outcrops and raw soils. 


\section{Present landscape structure in the conurbation of the cities of Martin and Vrútky in 2016}

In 2016, 17 areal landscape elements were identified in the study area (Table 3 ). The group consisting of tree and shrub vegetation again occupied the largest area (4 $649.98 \mathrm{ha}$ ). Forests which cover the western part of the study area are the most widespread landscape element (3 833.48 ha). Compared to 1993, the area of transitional woodlands/shrubs elements (399.81 ha) and non-forest timber vegetation (416.69 ha) which are also in the first group of elements increased significantly. Compared to 2003, the area group of agriculture crop elements slightly decreased (1 980.48 ha). On the contrary, the area of settlement and builtup areas increased (1 441.55 ha).

Table 3: Secondary landscape structure in study area (1993, 2003, 2016)

\begin{tabular}{|l|r|r|r|r|r|r|}
\hline \multicolumn{1}{|c|}{ Year } & \multicolumn{2}{c|}{$\mathbf{1 9 9 3}$} & \multicolumn{2}{c|}{$\mathbf{2 0 0 3}$} & \multicolumn{2}{c|}{$\mathbf{2 0 1 6}$} \\
\hline & \multicolumn{1}{|c|}{$\begin{array}{c}\text { Area } \\
\text { (ha) }\end{array}$} & \multicolumn{1}{c|}{$(\boldsymbol{\%})$} & \multicolumn{1}{c|}{$\begin{array}{c}\text { Area } \\
\text { (ha) }\end{array}$} & \multicolumn{1}{c|}{$(\boldsymbol{\%})$} & \multicolumn{1}{c|}{$\begin{array}{c}\text { Area } \\
\text { (ha) }\end{array}$} & $(\%)$ \\
\hline $\begin{array}{l}\text { 1 Tree and shrub } \\
\text { vegetation }\end{array}$ & $\mathbf{3 9 3 2 . 4 9}$ & $\mathbf{4 5 . 7 8}$ & $\mathbf{4 ~ 6 3 5 . 4 7}$ & $\mathbf{5 3 . 9 5}$ & $\mathbf{4 6 4 9 . 9 8}$ & $\mathbf{5 4 . 1 2}$ \\
\hline 11 Forest & 3760.95 & 43.78 & 3934.70 & 45.80 & 3833.48 & 44.62 \\
\hline $\begin{array}{l}\text { 12 Transitional } \\
\text { woodlands/shrubs }\end{array}$ & 25.05 & 0.29 & 309.51 & 3.60 & 399.81 & 4.65 \\
\hline $\begin{array}{l}\text { 13 Non-forest timber } \\
\text { vegetation }\end{array}$ & 146.49 & 1.71 & 391.26 & 4.55 & 416.69 & 4.85 \\
\hline 2 Grasslands & $\mathbf{1 3 2 1 . 0 6}$ & $\mathbf{1 5 . 3 8}$ & $\mathbf{4 4 9 . 7 9}$ & $\mathbf{5 . 2 4}$ & $\mathbf{3 9 9 . 2 6}$ & $\mathbf{4 . 6 5}$ \\
\hline 21 Meadows and pastures & 1321.06 & 15.38 & 449.79 & 5.24 & 399.26 & 4.65 \\
\hline 3 Agriculture crops & $\mathbf{1 9 6 3 . 4 0}$ & $\mathbf{2 2 . 8 6}$ & $\mathbf{2 ~ \mathbf { 0 1 9 . 1 8 }}$ & $\mathbf{2 3 . 5 1}$ & $\mathbf{1 9 8 0 . 4 8}$ & $\mathbf{2 3 . 0 5}$ \\
\hline 31 Arable land & 1416.21 & 16.48 & 1512.59 & 17.61 & 1462.84 & 17.03 \\
\hline 32 Gardens & 451.96 & 5.26 & 503.99 & 5.87 & 513.98 & 5.98 \\
\hline 33 Multiannual cultures & 95.23 & 1.12 & 0.00 & 0.00 & 0.00 & 0.00 \\
\hline $\begin{array}{l}\text { 34 Mosaics of agricultural } \\
\text { crops }\end{array}$ & 0.00 & 0.00 & 2.60 & 0.03 & 3.66 & 0.04 \\
\hline $\begin{array}{l}\text { 4 Sub-soil outcrops and } \\
\text { raw soils }\end{array}$ & $\mathbf{4 0 . 9 7}$ & $\mathbf{0 . 4 7}$ & $\mathbf{3 1 . 7 4}$ & $\mathbf{0 . 3 6}$ & $\mathbf{4 1 . 2 7}$ & $\mathbf{0 . 4 8}$ \\
\hline $\begin{array}{l}\text { 41 Sub-soil outcrops and raw } \\
\text { soils (natural) }\end{array}$ & 0.36 & 0.00 & 0.41 & 0.00 & 1.59 & 0.02 \\
\hline $\begin{array}{l}\text { 42 Sub-soil outcrops and raw } \\
\text { soils (artificial) }\end{array}$ & 40.61 & 0.47 & 31.33 & 0.36 & 39.68 & 0.46 \\
\hline
\end{tabular}




\begin{tabular}{|l|r|r|r|r|r|r|}
\hline \multicolumn{1}{|c|}{ Year } & \multicolumn{2}{c|}{$\mathbf{1 9 9 3}$} & \multicolumn{2}{c|}{$\mathbf{2 0 0 3}$} & \multicolumn{2}{c|}{$\mathbf{2 0 1 6}$} \\
\hline & \multicolumn{1}{|c|}{$\begin{array}{c}\text { Area } \\
\text { (ha) }\end{array}$} & $\mathbf{( \% )}$ & \multicolumn{1}{c|}{$\begin{array}{c}\text { Area } \\
\text { (ha) }\end{array}$} & \multicolumn{1}{c|}{$(\boldsymbol{\%})$} & \multicolumn{1}{c|}{$\begin{array}{c}\text { Area } \\
\text { (ha) }\end{array}$} & $(\boldsymbol{\%})$ \\
\hline $\begin{array}{l}\text { 5 Surface water and } \\
\text { wetlands }\end{array}$ & $\mathbf{8 6 . 8 4}$ & $\mathbf{1 . 0 1}$ & $\mathbf{7 1 . 3 9}$ & $\mathbf{0 . 8 3}$ & $\mathbf{7 8 . 7 4}$ & $\mathbf{0 . 9 2}$ \\
\hline 51 Water courses & 61.58 & 0.72 & 49.86 & 0.58 & 48.73 & 0.57 \\
\hline $\begin{array}{l}\text { 52 Standing waters and } \\
\text { wetlands }\end{array}$ & 25.26 & 0.29 & 21.53 & 0.25 & 30.1 & 0.35 \\
\hline $\begin{array}{l}\text { 6 Settlement and built-up } \\
\text { areas }\end{array}$ & $\mathbf{1 2 4 6 . 5 2}$ & $\mathbf{1 4 . 5 1}$ & $\mathbf{1 3 8 3 . 7 1}$ & $\mathbf{1 6 . 1 0}$ & $\mathbf{1 4 4 1 . 5 5}$ & $\mathbf{1 6 . 7 8}$ \\
\hline $\begin{array}{l}\text { 61 Housing and complex } \\
\text { amenities }\end{array}$ & 184.63 & 2.15 & 190.62 & 2.22 & 202.18 & 2.35 \\
\hline $\begin{array}{l}\text { 62 Urban and technical } \\
\text { vegetation }\end{array}$ & 422.76 & 4.92 & 545.28 & 6.35 & 549.40 & 6.39 \\
\hline 63 Sports facilities & 25.99 & 0.30 & 29.10 & 0.34 & 29.31 & 0.34 \\
\hline $\begin{array}{l}\text { 64 Recreational facilities and } \\
\text { resort }\end{array}$ & 3.17 & 0.04 & 3.65 & 0.04 & 4.33 & 0.05 \\
\hline $\begin{array}{l}\text { 65 Industrial and technical } \\
\text { objects and areas }\end{array}$ & 279.37 & 3.25 & 249.57 & 2.90 & 266.56 & 3.10 \\
\hline $\begin{array}{l}\text { 66 Transport objects and } \\
\text { areas }\end{array}$ & 330.60 & 3.85 & 365.49 & 4.25 & 389.76 & 4.54 \\
\hline Total & $\mathbf{8 5 9 1 . 2 8}$ & $\mathbf{1 0 0}$ & $\mathbf{8 5 9 1 . 2 8}$ & $\mathbf{1 0 0}$ & $\mathbf{8 5 9 1 . 2 8}$ & $\mathbf{1 0 0}$ \\
\hline
\end{tabular}

\section{Evaluation of development trends}

In Table 4 we can see 14 development trends in individual periods which were identified by comparing the changes of secondary landscape structure in our study area. Evaluation of development trends demonstrated relatively small changes in both time periods. The larger percentage of changes occurred in the first period between 1993 and 2003. Altogether $21.05 \%$ of the area had changed. The strongest development trend in the first period was afforestation $(8.53 \%)$. It was mainly reflected by the significant increase of non-forest timber vegetation. Deforestation was also strong during the first period (3.71\%) and similar in the second period $(3.73 \%)$. The trend of agricultural intensification (3.29\%) was strong in first period but in the second period this trend had significantly decreased $(0.27 \%)$. Since 1993, there has been a decline in agricultural land in the Slovak Republic, while after the accession of the Slovak Republic to the EU it has increased (Boltižiar et al., 2016). Urbanisation (1.89\%) and industrialisation $(0.92 \%)$ trends were connected with the loss of agricultural land (1.52\%). 
Table 4: Development trends of study area in 1993-2003 and 2003-2016

\begin{tabular}{|l|r|r|r|r|}
\hline \multicolumn{1}{|c|}{ Year } & \multicolumn{2}{|c|}{$\mathbf{1 9 9 3 - 2 0 0 3}$} & \multicolumn{2}{c|}{$\mathbf{2 0 0 3 - 2 0 1 6}$} \\
\hline Trends & Area (ha) & Area (\%) & Area (ha) & Area (\%) \\
\hline Unchanged & 6782.80 & 78.95 & 7806.40 & 90.86 \\
\hline Urbanisation & 162.24 & 1.89 & 32.16 & 0.37 \\
\hline Deurbanisation & 27.74 & 0.32 & 4.46 & 0.05 \\
\hline Industrialization & 78.77 & 0.92 & 28.87 & 0.34 \\
\hline Deindustrialisation & 11.79 & 0.14 & 3.48 & 0.04 \\
\hline $\begin{array}{l}\text { Exploitation of mineral } \\
\text { resources }\end{array}$ & 15.14 & 0.18 & 7.71 & 0.09 \\
\hline Agricultural intensification & 282.72 & 3.29 & 23.07 & 0.27 \\
\hline Agricultural extensification & 18.96 & 0.22 & 0.07 & 0.00 \\
\hline Afforestation & 733.12 & 8.53 & 286.96 & 3.34 \\
\hline Deforestation & 318.98 & 3.71 & 320.78 & 3.73 \\
\hline Flooding & 2.55 & 0.03 & 2.43 & 0.03 \\
\hline Draining & 0.87 & 0.01 & 0.02 & 0.00 \\
\hline Environment remediation & 25.43 & 0.30 & 1.28 & 0.01 \\
\hline Loss of agricultural land & 130.17 & 1.52 & 73.59 & 0.86 \\
\hline Total & $\mathbf{8 5 9 1 . 2 8}$ & $\mathbf{1 0 0 . 0 0}$ & $\mathbf{8 5 9 1 . 2 8}$ & $\mathbf{1 0 0 . 0 0}$ \\
\hline
\end{tabular}

During the second period the study area was more stable in terms of land use. Only $9.14 \%$ of the study area changed. Trends of deforestation (3.73\%) and of afforestation (3.34\%) were balanced. This was caused by the logging of wood as a result of reaching the trees' ages and at the same time by the vegetation growth in pastures and meadows due to a significant decline in cattle breeding. Despite the declining values, there was still a loss of agricultural land $(0.86 \%)$ at the expense of industrialization $(0.34 \%)$ and urbanization $(0.37 \%)$ which was reflected mainly in the construction of flats and houses.

\section{Conclusion}

The aim of this paper was to identify and evaluate development trends in the conurbation of the cities of Martin and Vrútky based on the comparison of land use changes over the last 23 years.

The largest changes took place in the first time period. They were caused mainly by the change of regime in 1989. Transformation of agricultural cooperatives, restitution of private property and privatization of enterprises also reflected by land use. The strongest development trend was afforestation. The trend of agricultural intensification occurred as a result of the conversion of grasslands into large-block fields. This was directly related to a decline in cattle breeding. In 
some unused grasslands, the non-forest timber vegetation started to grow. Since 2000, new foreign investors have been arriving in this area. Large industrial parks were constructed leading to an increase in employment and living standards. Therefore the trends of loss of agricultural land, urbanisation and industrialization are significant.

In terms of changes, the second period which represents the period after Slovakia's accession to the European Union is relatively stable. Compared to the first period, we can see a decrease in all development trends. Considering the fact that trends of afforestation and deforestation were balanced, we can say the most significant trend was loss of agricultural land at the expense of new industrial enterprises which have slowly arisen around both cities. As a result of the increase in the standard of living the process of urbanisation is also visible in several urban areas in the form of family houses and sports and recreational facilities. The new motorway section also influenced the character of the landscape. It is possible that in the future it will also have a great impact on the ongoing industrialisation and urbanisation of the study area.

At present, land re-parcelling could have the most significant influence on the landscape, which could influence not only ownership but also land use change (Muchová, Leitmanová, Petrovič 2016, Muchová, Konc, Petrovič 2018), as well as the modification of hydrological conditions in floodplains (Horáčková et al. 2018, Jakubcová et al. 2016, Petrovič et al. 2017).

Monitoring of the dynamics of changes in the study area can contribute to an understanding of the historical development of land use and can ensure its sustainable development and support the solution of its potential landscape ecological problems.

\section{Acknowledgement}

The paper was prepared within the grant project of Slovak Scientific Grant Agency VEGA no. 1/0496/16.

\section{References}

BOLTIŽIAR, M. - OLAH, B. - GALLAY, I. - GALLAYOVÁ, Z. 2016. Transformation of the Slovak cultural landscape and its recent trends. In Landscape and landscape ecology : Proceedings of the 17th International Symposium on Landscape Ecology. Bratislava: Institute of Landscape Ecology SAS, 2016. ISBN 978-80-89325-28-3, pp. 57-67.

BÜRGI, M. - HERSPERGER, A. M. - SCHNEEBERGER, N. 2004. Driving Forces of Landscape Change - Current and New Directions. In Landscape Ecology. vol. 19, pp. 857-868. 
CEBECAUEROVÁ, M. 2007. Analýza a hodnotenie zmien štruktúry krajiny (na príklade časti Borskej nížiny a Malých Karpát). In Geographica Slovaca. vol. 24, pp. 23-26.

CEBECAUEROVA, M. - CEBECAUER, T. 2005. Specific visualizations of land cover changes as a tool of landscape cognition. In Kartografické listy. roč. 13, č. 9 .

FERANEC, J. - ŠÚRI, M. - CEBECAUER, T. - OŤAHEL', J. 2002. Methodological aspects of landscape changes detection and analysis in Slovakia applying the CORINE land cover databases. In Geographical Journal. vol. 54, no.3, pp 255-270.

HALADOVÁ, I. - PETROVIČ, F. 2017. Predicted development of the city of Nitra in Southwestern Slovakia based on land cover-land use changes and socio-economic conditions. In Applied Ecology and Environmental Research. vol. 15 , no. 4, pp 987-1008.

HAVLÍČEK, M. et al. 2018. The consequences of establishing military training areas for land use development - A case study of Libavá Czech Republic. In Land Use Policy. vol. 73, pp. 84-93.

HERSPERGER, A.M. - BÜRGI M. 2009. Going beyond landscape change description: quantifying the importance of driving forces of landscape change in a Central Europe case study. In Land Use Policy. vol. 26, pp. 640-648.

HREŠKO, J. - BUGÁR, G. - BOLTIŽIAR, M. - KOHÚT, F. 2008. Dynamics of recent geomorphic processes in alpine zone of the Tatra Mts. In Geographia Polonica. ISSN 0016-7282, 2008, vol. 81, no. 1, pp. 53-65.

HORÁČKOVÁ, Š. et al. 2018. Historical changes and vegetation development after intensive peat extraction in the lowland mires of Slovakia. In Applied Ecology and Environmental Research. vol. 16, no. 4, pp. 5025-5045.

JAKUBCOVÁ, A. et al. 2016. Impacts of Flooding on the Quality of Life in Rural Regions of Southern Slovakia. In Applied Research in Quality of Life. vol. 11, no. 1, pp. 221-237.

IZAKOVIČOVÁ, Z. - MEDERLY, P. - PETROVIČ, F. 2017. Long-term land use changes driven by urbanisation and their environmental effects (example of Trnava City, Slovakia). In Sustainability (Switzerland). vol. 9, no. 9, pp. 1553.

LIESKOVSKÝ, J. - KAIM, D. - BALÁZS, P. - BOLTIŽIAR, M. - CHMIEL, M. - GRABSKA, E. - KIRÁLY, G. - KONKOLY-GYURÓ, E. - KOZAK, J. ANTALOVÁ, K. - KUCHMA, T. - MACKOVČIN, P. - MOJSES, M. MUNTEANU, C. - OSTAFIN, K. - OSTAPOWICZ, K. - SHANDRA, O. STYCH, P. - RADELOFF, V. C. 2018. Historical land use dataset of the Carpathian region (1819-1980). In Journal of Maps. ISSN 1744-5647, 2018, vol. 14, no. 2, pp. 644-651.

LIPSKÝ, Z. 2000. Sledování změn v kulturni krajině. Praha: ČZU, 2000. 71 s. ISBN 80-213-0643-2. 
LÖFVENHAFT, K. - RUNBORG, S. - SJÖGREN-GULVE P. 2004. Biotope patterns and amphibian distribution as assessment tools in urban landscape planning. In Landscape and Urban Planning. vol. 68, pp. 403-427.

MIKLÓS, L. - IZAKOVIČOVÁ, Z. 1997. Krajina ako geosystém. Bratislava: Veda, 1997. ISBN 80-224-0519-1.

MUCHOVÁ, Z. - LEITMANOVÁ, M. - PETROVIČ, F. 2018. Land plots valuation in land consolidation in Slovakia: A need for a new approach. In International Journal of Strategic Property Management. vol. 22, no. 5, pp. 372-380.

MUChOVÁ, Z. - LEITMANOVÁ, M. - PETROVIČ, F. 2016. Possibilities of optimal land use as a consequence of lessons learned from land consolidation projects (Slovakia). In Ecological Engineering. vol. 90, pp. 294-306.

MUNTEANU, C. - KUEMMERLE, T. - BOLTIŽIAR, M. - LIESKOVSKÝ, J. MOJSES, M. - KAIM, D. - GUYRÓ, É. K. - MACKOVČIN, P. - MÜLLER, D. - OSTAPOWICZ, K. - RADELOFF, V. C. 2017. Nineteenth-century landuse legacies affect contemporary land abandonment in the Carpathians. In Regional Environmental Change. vol. 17, no. 8, pp. 2209-2222.

NASSAUER, J. I. 1995. Culture and changing landscape structure. In Landscape Ecology. vol. 10, pp. 229-237.

PETROVIČ, F. - BUGÁR, G. - HREŠKO, J. 2009. Zoznam krajinných prvkov mapovatel'ných na území Slovenska. In GEO Information. vol. 5, pp. 112-124.

PETROVIČ, F. et al. 2017. Landscape-ecological optimization of hydric potential in foothills region with dispersed settlements - a case study of Nová Bošáca, Slovakia. In Applied Ecology and Environmental Research. vol. 15, no. 1, pp. 379-400.

SCHNEEBERGER, N. - BÜRGI, M. - HERSPERGER, A. M. - EWALD K. C. 2007. Driving forces and rates of landscape change as a promising combination for landscape change research - an application on the northern fringe of the Swiss Alps. In Land Use Policy. vol. 24, pp. 349-361.

\section{Mgr. Bc. Jana Nozdrovická}

Ing. Martina Turanovičová

Department of Ecology and Environmental Sciences

Constantine the Philosopher University in Nitra

Trieda A. Hlinku 1, 94974 Nitra, Slovak Republic

E-mail: jana.nozdrovicka@ukf.sk,martina.turanovicova@ukf.sk

\section{Mgr. Petra Gašparovičová}

Institute of Landscape Ecology

Slovak Academy of Sciences

Akademická 2, 94910 Nitra, Slovak Republic

E-mail: petra.gasparovicova@ savba.sk 